\title{
Destressing the ROB5 Remnant Using Tight Slot Blasting at Mt Charlotte Mine
}

\author{
M. Kempin Kalgoorlie Consolidated Gold Mines Pty Ltd, Australia
}

A. Sprague Sprague Geological Engineering, Australia

S. Narendranathan Kalgoorlie Consolidated Gold Mines Pty Ltd, Australia

P.A. Mikula Mikula Geotechnics Pty Ltd, Australia

M.F. Lee AMC Consultants Pty Ltd, Australia

\begin{abstract}
The Mt Charlotte ROB5 orebody remnant had defeated two earlier attempts at stoping, with Richter magnitude $\left(M_{R}\right) 2.2$ to 2.9 seismic events in 1995 and 1997 causing a halt to production.

A destressing strategy, known as Tight Slot Blasting (TSB), was subsequently developed for this orebody. It was designed to manage fault-slip seismicity on several major structures intersecting the ROB5 area. The objective was to destress by creating a slot $150 \mathrm{~m}$ long and up to $40 \mathrm{~m}$ high along the entire western edge of the orebody. The concept was validated using a calibrated numerical modelling study, and the key elements involved tight firing (low blast expansion void) and rapid firing (electronic detonation).

Mining commenced in August 2006. At that time, four particular R-shears (sub-vertical and striking NE-SW) were identified as requiring specific seismic management. A blasting schedule was defined using four TSB segments to advance the slot across these structures. To date, two TSBs have been conducted and $80 \%$ of the orebody has been destressed, but practical blasting issues have affected the project, and fault-slip seismicity has also been experienced.

Bridging of intact rock across the slot has been a major problem, and methods of dealing with this have been developed. The main issue was long up-holes that toed into highly stressed, fractured and open ground below the previous ROB5 undercut.

The largest fault-slip event, $M_{R}+2.2$, was the same as the project maximum that was estimated in 2004. Ground support has generally performed well. The TSB strategy has provided the required control of event magnitude, but not event timing. This is a significant project. It has added 18 months to the life of the mine, and represents a rare attempt to achieve stope-scale destressing in the face of fault-slip seismicity.
\end{abstract}

\section{Introduction}

Significant seismicity at Mt Charlotte is often associated with shearing on major structures where they intersect or pass close to stoping blocks. There have been positive experiences at Mt Charlotte with both preconditioning and destress slotting, but not universal success.

As the mine is located adjacent to the Kalgoorlie-Boulder township, there is a requirement for low surface vibrations resulting from mining activities. Events must be less than about $\mathrm{M}_{\mathrm{R}}+2.3$ to meet surface vibration limits.

The I1 stope pillar was preconditioned in 1995 with the aim of decreasing the seismic risk. This was followed by the small C4 destressing project in 1999. Destressing is now a standard proactive tool to reduce and manage seismicity at Mt Charlotte.

Building on the understanding of seismicity gained at Mt Charlotte over many years (Mikula and Lee, 2002) a new procedure for seismicity management, Tight Slot Blasting (TSB), was formulated by Kalgoorlie Consolidated Gold Mines (KCGM) and AMC Consultants (Sharrock, 2004). It comprised controlled tight 
blasting of a narrow slot along the $150 \mathrm{~m}$ length of the ROB5 orebody remnant below the original stope. The height of this slot, over the 24 to 25 Level interval, varied from $35 \mathrm{~m}$ to $40 \mathrm{~m}$.

The TSB slot is not a conventional mining slot. It is the creation of a tightly packed zone of broken rock, positioned to destress the rock mass and allow controlled dampened shearing on critical geological structures, rather than violent strain energy release. Precise blast designs and accurate implementation is vital to achieve the required stress cut-off before structural shearing occurs. TSB is an alternative to conventional destress techniques such as slotting, blasting, preconditioning, or hydraulic pressurisation. It differs from the other techniques in that it reduces stresses by removing the rock, but immediately replacing it with a tightly packed zone of blasted rock of greatly reduced modulus.

Unless stated otherwise, seismic event magnitudes in this report are given as equivalent Richter magnitudes $\left(\mathrm{M}_{\mathrm{R}}\right)$, orientations are with respect to the Mine Grid and depths (BD) are with respect to the mine datum. 25 Level, the focus of the project, is $780 \mathrm{~m} \mathrm{BD}$.

\section{ROB5 Stoping Block}

Previous mining: Seismicity in the ROB5 stoping block has been an enigma. The primary ROB5 open stope was very large $-280 \mathrm{~m}$ long, up to $135 \mathrm{~m}$ high and $70 \mathrm{~m}$ wide (Figures 1 and 2). It was mined in 1990-1994 between 21 and 25 Level and from north to south. High stresses, extensive back overbreak and seismicity were experienced, but despite mining through several major structures (R-shears), significant seismicity did not occur until later.

With primary mining complete, remnant ore remained in the 24 to 25 Level R52 block below the northern two-thirds of the stope. New 25 Level development was mined for a proposed transverse sub-level cave (SLC), but retreating south to north. However, the first production blast (28 January 1995) had a large concurrent seismic event $\left(\mathrm{M}_{\mathrm{R}}+2.9\right)$ involving slip on R5-shear. Further stoping was abandoned.

An intermediate 24A Level was then mined to longitudinally SLC 24 to 25 Level back to a central waste pillar. This development exposed a $30 \mathrm{~m}$ length of R3-shear, which was the focus of major seismicity on 17 March $1997\left(\mathrm{M}_{\mathrm{R}}+2.2\right.$ and +2.6). Complex shear displacement occurred on three steeply dipping shears (R3, R3A and R4), and a moderate west dipping structure (Shea Fault). This mining strategy was also abandoned.

To stabilise the void and in preparation for an anticipated mine closure in 2001, due to low gold prices, the large ROB5 void was filled with mullock via two tipping points on 21 Level. The Tight Slot Blast (TSB) strategy for the R52 remnant, which is the subject of this paper, represents the third attempt to mine this R52 block. The primary ROB5 stope (planned plus back overbreak) was 3,140,000 tonnes, increasing to $3,750,000$ tonnes with the R52 remnant.

Sub-vertical shears: The ROB5 stoping block is bounded by two major sub-vertical northeast striking faults - Reward Fault to the north and Maritana Fault on the southern end. Several R-shears (some shown in Figure 1) are sub-parallel to Reward Fault and transect the stope block at 20 to $50 \mathrm{~m}$ intervals. They typically comprise one or several tight sub-parallel semi-continuous surfaces.

Moderate west-dipping structures: Shea Fault dips approximately $45^{\circ}$ to the west and intersects the stoping block, as does the S1-shear which is sub-parallel to Shea Fault. In the prevailing geometry and stress field, both the R-shears and the west-dipping structures experience high shear stresses. The R-shears have numerous minor offsets at intersections with the west-dipping structures, but unfortunately offset locations and styles cannot be easily determined. Offsets, in combination with undulations (roughness), can cause locking on both structure sets. Shear may be difficult even in a slip-favourable stress state, but when it does occur, significant seismicity is possible. 


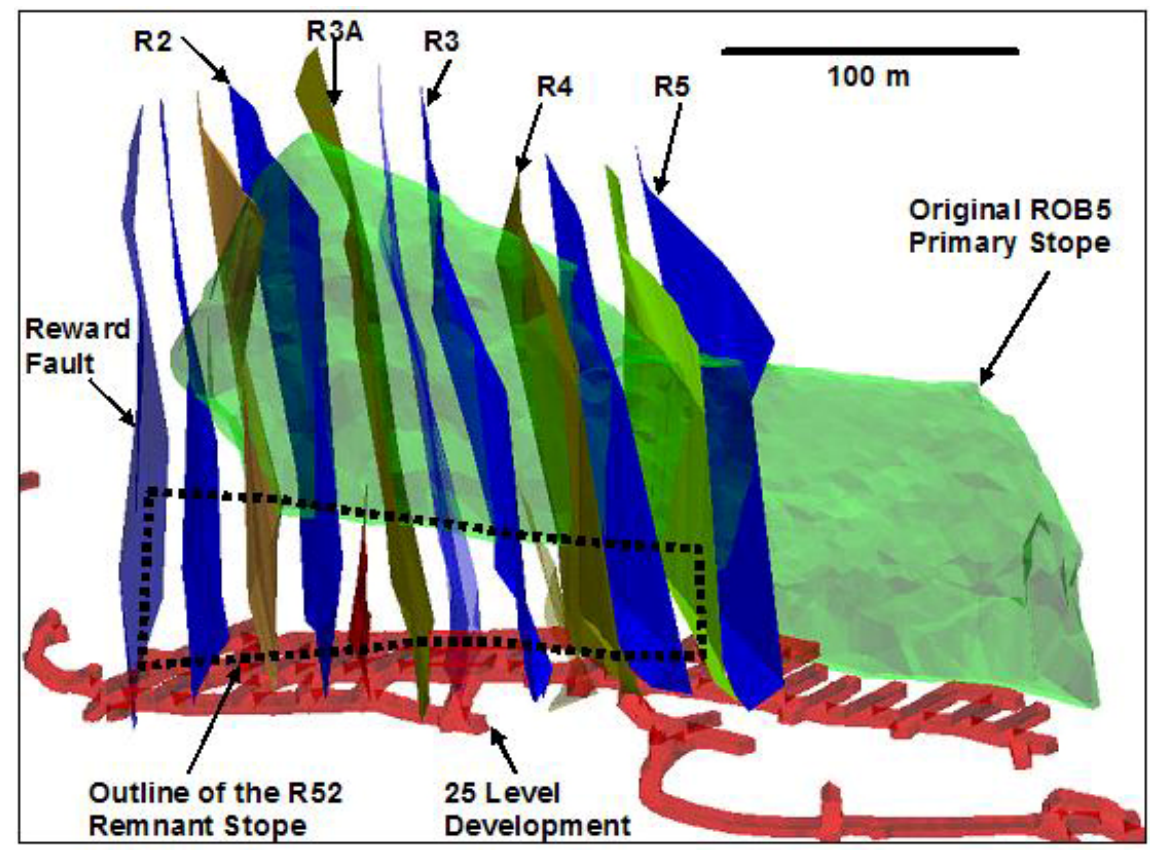

Figure 1 Perspective view of the ROB5 area showing the larger subvertical structures - the westdipping structures are omitted for clarity

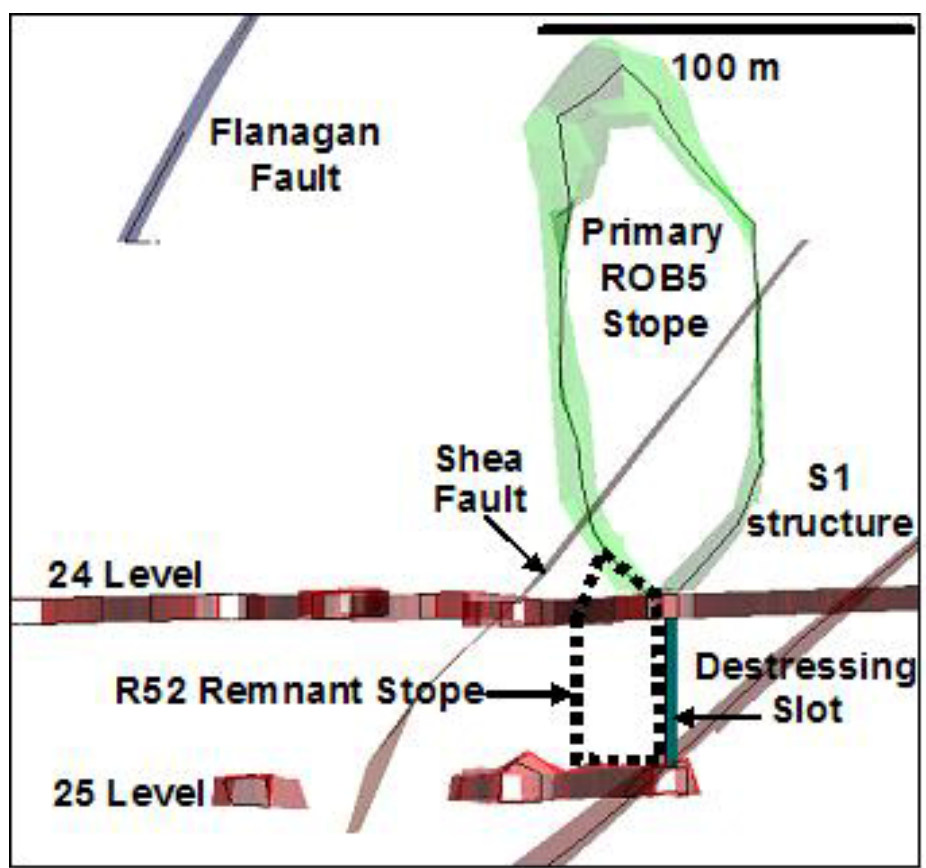

Figure 2 An east-west cross-section slice through the mining area, showing the major west-dipping structures transecting the stoping area

Clearly, knowledge of geological structures is the first step to managing seismicity. Previous computer interpretations of some faults were found to be erroneous, and needed correction. All of the ROB5 structures that had a continuity exceeding 10 by $10 \mathrm{~m}$ were mapped. The larger features were surveyed, wire framed and their likely stability was considered prior to every firing.

Rock Properties: Reliable intact rock and rock mass properties for Mt Charlotte are available (Table 1) with further information in Lee and Fotakis (1992). 
Table 1 Intact rock and rock mass properties

\begin{tabular}{l|c|c|c|c|c}
\hline Rock Type & $\begin{array}{c}\mathbf{U C S}_{\mathbf{5 0}} \\
\text { (MPa) }\end{array}$ & $\begin{array}{c}\text { UCS in situ } \\
\mathbf{( M P a )}\end{array}$ & $\mathbf{v}$ & $\begin{array}{c}\text { E } \\
\text { (GPa) }\end{array}$ & $\begin{array}{c}\text { *Rock mass strength } \\
\text { (MPa) }\end{array}$ \\
\hline Dolerite Unit 7 (hangingwall) & 152 & $\sim 80$ to 90 & 0.34 & 84 & \\
Dolerite Unit 8 (stope) & 177 & $\sim 80$ & 0.22 & 65 & $\sigma_{1}=60+2 \sigma_{3}$ \\
Dolerite Unit 9 (footwall) & 167 & $\sim 80$ & 0.18 & 69 & \\
\hline
\end{tabular}

* Derived from a back-analysis of the I1 Rib Pillar monitoring (Mikula and Lee, 2002)

* Derived from a back-analysis of the I1 Rib Pillar monitoring (Mikula and Lee, 2002)

Stresses: Seven in-situ rock stress measurements have been done at Mt Charlotte. The measurement done on 24 Level (overcoring of CSIRO HI cells at $735 \mathrm{~m} \mathrm{BD} \mathrm{depth)} \mathrm{close} \mathrm{to} \mathrm{the} \mathrm{area} \mathrm{of} \mathrm{interest} \mathrm{was:}$

$\begin{array}{lll}\sigma_{1} & = & \left.64 \mathrm{MPa} \text {, sub-horizontal north-south (dipping } 13^{\circ} \text { towards } 177^{\circ}\right) . \\ \sigma_{2} & = & \left.37 \mathrm{MPa} \text {, sub-horizontal east-west (dipping } 12^{\circ} \text { towards } 269^{\circ}\right) . \\ \sigma_{3} & = & \left.21 \mathrm{MPa} \text {, sub-vertical (dipping } 72^{\circ} \text { towards } 039^{\circ}\right) .\end{array}$

\section{Tight slot blast decision}

The TSB proposal was investigated and reported previously (Mikula et al., 2005). Map3D modelling undertaken by AMC Consultants (Sharrock, 2004) showed that the principle was sound for shearing on Rshears. While this work was able to forecast potential event magnitudes, it was based on a range of assumptions and simplifications, in particular regarding offsets that may lock up some structures. Estimates of maximum magnitudes, due to shearing on R-shears, Reward or Shea Faults were:

- Worst case, without the TSB strategy: $\mathrm{M}_{\mathrm{R}}+2.0$ to +2.9 .

- Best case, with the TSB strategy: $\quad \mathrm{M}_{\mathrm{R}}+1.3$ to +2.2 .

This was encouraging, suggesting that the TSB strategy could meet the required $\mathrm{M}_{\mathrm{R}}<+2.3$ target. But the large differences between the best and worst cases for the TSB highlighted that it had to be properly engineered to achieve the best case results. After due consideration and for the following reasons, it was decided to proceed with mining the R52 stoping block:

- The cause of the previous large seismic events in ROB5 was explained.

- There was now significantly more experience and understanding of stress management principles, than a decade ago. There was better understanding of ground conditions and of elements critical to seismicity (structures, orientations, off-sets, stresses and shear stresses mobilised on structures).

- The use of destressing drives to manage seismic hazard was becoming accepted practice at Mt Charlotte. The proposed TSB would generate more stress shadowing, compared to preconditioning.

- Modelling demonstrated that the revised mining sequence helped reduce event magnitude.

- The mine now accepted SLC mining and no longer required large clean stopes. ROB5 was now backfilled, and not a large void. Backfilling dampens seismicity and there is a suggestion (Mikula, 2001) that fill has reduced seismic event magnitudes by about 0.4 at Mt Charlotte.

- Better and more accepted ground support practices were now available for managing seismically active ground conditions (fibrecrete, mesh and mixtures of bolts rather than just one bolt type).

- Better blasting practices were now available (electronic detonators).

- The ROB5 area has been seismically dormant for several years. This suggests that equilibrium has been attained via gradual aseismic creep, but some structures may still be locked-up on offsets. 
- An upgraded seismic monitoring system would be installed with additional sensors in the ROB5 area, to monitor events down to $\mathrm{M}_{\mathrm{R}}-2$.

- New seismic analysis and 3D visualisation packages were now available to monitor developing clusters of seismic activity, enabling pre-empting of problem areas with increased ground support and/or personnel exclusions.

It is Mt Charlotte's experience, and a very important design principle, that closure pillars should be avoided. However as the stoping block was bounded by Reward Fault to the north and previous mining to the south, stoping would close either onto the fault, or form a closure pillar with the previous mining. Both presented potential high stress problems. The choice between the two was one of the most important judgements for this project.

After exhaustive studies it was decided to close with the previous stoping and that the final slotting interval would be from about millholes $\mathrm{G}$ to I (see Figure 3). This interval was considered to be partly destressed due to prior movements on structures, with associated seismicity. It was also more structured, so shearing should occur more readily, i.e. less storage of energy. No known locked-up structures intersected the interval, and Shea Fault was located significantly further west of this slotting interval, compared to its position at B millhole.

\section{Slot mining chronology}

The adopted mining plan, which varied slightly from that in the original Map3D modelling, comprised the steps shown in Table 2 and Figure 3. The plan involved uphole retreat with several TSBs from 25 Level. While uphole retreat was not ideal for brow stability, due to high brow stresses, it was thought to be manageable with appropriate ground support.

Four particular structures (R2, R3, R3A and R4) were identified as requiring specific seismic management, and separate TSB segments were planned across each. Slot raises for the TSB were positioned about $5 \mathrm{~m}$ from each R-shear.

It was recognised that slotting could compromise the stability of Shea Fault especially in the floor of 25 Level, and floor heave was possible. Destress blasting of the floor down to intersect Shea Fault was considered but not actioned, but in hindsight should probably have been done.

\section{$5 \quad$ Slot blasting progress and problems}

Up to 29 August 2007, 80\% of the $150 \mathrm{~m}$ long slot has been mined. Two TSB blasts have been completed, a third was cancelled (see Table 2) and a fourth is scheduled for September 2007.

Slotting has been slow due to practical blasting issues. Bridging of intact rock across the slot has been a major problem, and various methods have been used to alleviate the problem. Mining a narrow slot in highly stressed ground is not a trivial exercise. Table 3 presents the optimised design parameters based on experience gained during this project.

The original TSB concept required that the fired rock was not mucked or loosened, but it should remain in place until the SLC millhole extraction retreated away from it. However this did not happen due to bridges formed across the slot and production requirements for tonnes. These circumstances increased the seismic hazard - both the chance of seismicity and the magnitude of possible events.

Bridges. Bridging has been significant. A bridge developed above the slot, a few metres thick, just below 24 Level from millhole $\mathrm{C}$ to the current brow approximately $11 \mathrm{~m}$ short of millhole $\mathrm{G}$. A second bridge affected the southern end of the slot (south of millhole I). Also a small (11 m long) pillar remained between millholes D and E, from 24 to 25 Level. 
Table 2 The implementation stages for the ROB5 TSB project. Locations of key activities are shown in plan view in Figure 3. Only major seismicity is noted

\begin{tabular}{|c|c|c|c|}
\hline Date & Activity & Comment & Seismicity Response \\
\hline $\begin{array}{l}\text { Aug/Oct } \\
06\end{array}$ & $\begin{array}{l}\text { Millhole } \\
\text { A mined }\end{array}$ & $\begin{array}{l}\text { Preparatory slot retreat to mine } \\
\text { the east-west millhole A and } \\
\text { expose Reward and Shea Faults. }\end{array}$ & $\begin{array}{l}\text { Numerous events, not large - still } \\
\text { small extent of mining. }\end{array}$ \\
\hline Nov 06 & $\begin{array}{l}\text { South slot } \\
\text { started }\end{array}$ & $\begin{array}{l}\text { This slot advanced from millhole } \\
\text { L, northwards along } 2515 \text { drive. }\end{array}$ & $\begin{array}{l}\text { Comparatively few smaller events in } \\
\text { this area. }\end{array}$ \\
\hline Nov 06 & $\begin{array}{l}\text { North slot } \\
\text { started }\end{array}$ & $\begin{array}{l}\text { This slot advanced south along } \\
2515 \text { drive. However bridging } \\
\text { developed below } 24 \text { Level and } \\
\text { worsened with successive blasts. }\end{array}$ & $\begin{array}{l}\text { Seismic response increasing, mainly } \\
\text { ahead of the slot brow. }\end{array}$ \\
\hline 12 Jan 07 & First TSB & $\begin{array}{l}\text { Rings } 512-520 \text { across } \mathrm{R} 2 \text { at } \\
\text { millhole } \mathrm{C} \text {. Blast did not break to } \\
\text { full height. }\end{array}$ & $\begin{array}{l}\text { 18-Jan- } 07 \mathrm{M}_{\mathrm{R}}+2.2-\text { Shearing on } \\
\text { Shea Fault from Reward fault to R3 } \\
\text { shear. Damage on } 25 \mathrm{~L} \text { and } 2435 \mathrm{~L} \text {. }\end{array}$ \\
\hline Feb 07 & South slot & $\begin{array}{l}\text { South slotting front paused at } \\
\text { millhole I. }\end{array}$ & \\
\hline Feb 07 & North slot & $\begin{array}{l}\text { New 5-hole slot design pattern } \\
\text { performed much better. }\end{array}$ & \\
\hline 13 Mar 07 & Blast & $\begin{array}{l}\text { Blast caused major brow damage } \\
\text { such that the next } 4 \text { rings collars } \\
\text { were lost. }\end{array}$ & $\begin{array}{l}13 \text {-Mar- } 07 \mathrm{M}_{\mathrm{R}}+1.3 \text { - Located at the } \\
\text { brow of the advancing destress slot. }\end{array}$ \\
\hline 21 Mar 07 & Blast & $\begin{array}{l}\text { Bridge above millhole D finally } \\
\text { removed, backfill mobilised into } \\
\text { stope. }\end{array}$ & $\begin{array}{l}\text { 27-Mar- } 07 \mathrm{M}_{\mathrm{R}}+0.9 \text { - Located in } \\
\text { ROB5 western side abutment above } \\
\text { 24L. }\end{array}$ \\
\hline 28 Mar 07 & $\begin{array}{l}\text { Second } \\
\text { TSB }\end{array}$ & $\begin{array}{l}\text { Rings } 528-532 \text { across R } 3 \mathrm{~A} \text { at } \\
\text { millhole E. However a slot pillar } \\
\text { and bridging remained after the } \\
\text { blast. }\end{array}$ & $\begin{array}{l}21-\mathrm{Apr}-07 \mathrm{M}_{\mathrm{R}}+1.8-\text { Shear on } \mathrm{R} 2 \\
\text { structure at } 26 \mathrm{~L} \text {, about } 30 \mathrm{~m} \text { below } \\
25 \mathrm{~L} \text {. High deformation and energy } \\
\text { release source parameters show that } \\
\text { destressing extended that far. }\end{array}$ \\
\hline 28 May 07 & Blast & $\begin{array}{l}\text { Bridge south of millhole } \mathrm{E} \text { finally } \\
\text { broken. }\end{array}$ & $\begin{array}{l}\text { 4-Jun-07 } \mathrm{M}_{\mathrm{R}}+1.7-\text { Shear on } \mathrm{S} 1- \\
\text { structure in } 2535 \text { drive and the full } \\
\text { remaining } 2515 \text { slot. } 19 \mathrm{MPa} \text { stress } \\
\text { rise in flatjack reading at millhole G. } \\
\text { This event introduced a marked } \\
\text { change in seismicity response. }\end{array}$ \\
\hline 26 Jun 07 & Blast & $\begin{array}{l}\text { Blast successfully removed the } \\
\text { slot pillar and bridges. }\end{array}$ & $\begin{array}{l}\text { Several events } M_{R}+1.0 \text { or less in the } \\
\text { vicinity of Reward Fault. }\end{array}$ \\
\hline $13 \mathrm{Jul} 07$ & $\begin{array}{l}\text { South slot } \\
\text { restarted }\end{array}$ & $\begin{array}{l}\text { First south slot firing since } \\
\text { February. Commences the } \\
\text { mining of the final closure } \\
\text { interval. }\end{array}$ & Minor events only. \\
\hline July 07 & $\begin{array}{l}\text { Cancelled } \\
\text { the third } \\
\text { TSB }\end{array}$ & $\begin{array}{l}\text { Decision taken to cross the } \mathrm{R} 4 \\
\text { using conventional single-ring } \\
\text { advance. }\end{array}$ & $\begin{array}{l}\text { Events } M_{R}+0.6 \text { or less since mid- } \\
\text { July } 2007 \text {. Observations showed the } \\
\text { area was already destressed. }\end{array}$ \\
\hline (future) & $\begin{array}{l}\text { Fourth } \\
\text { TSB }\end{array}$ & $\begin{array}{l}\text { To cross R3 and remove the final } \\
\text { closure pillar }\end{array}$ & \\
\hline
\end{tabular}




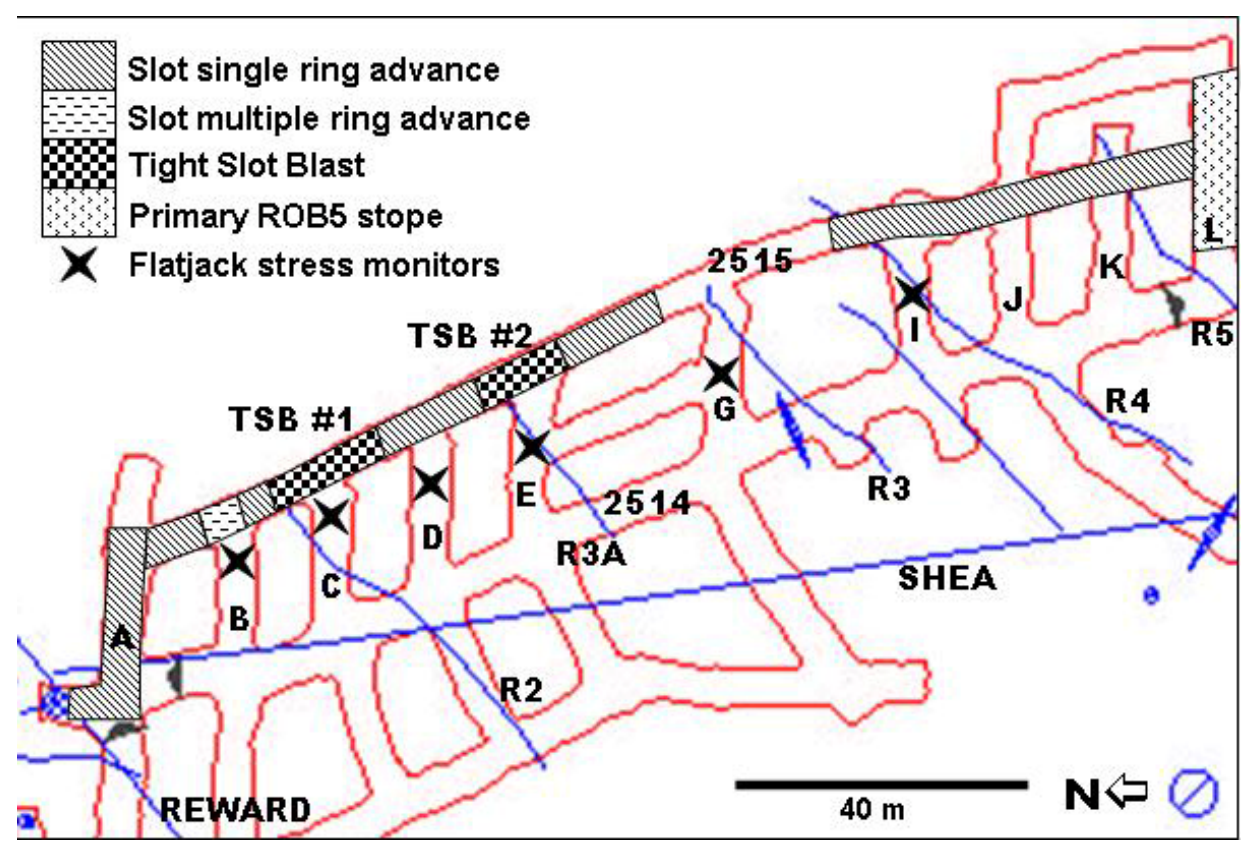

Figure 3 Plan of 25 level showing major stages in the mining of the R52 slot and location of stress monitors

Table 3 Optimised blast design parameters for a tight slot blast

Pattern $\quad 2 \mathrm{~m}$ burden; $2.5 \mathrm{~m}$ spacing; $89 \mathrm{~mm}$ holes; each ring comprising 5 main holes at $100^{\circ}$ inclination, plus 2 easers on $105^{\circ}$ to assist the ring mid-to-toe section.

\begin{tabular}{ll}
\hline Powder Factor & Maintain $>0.5 \mathrm{~kg} / \mathrm{m}^{3}$ in stressed seismic ground. \\
\hline Timing & $100 \mathrm{~ms}$ between holes; $400 \mathrm{~ms}$ offset of timing between multiple rows. \\
\hline Intersections & $\begin{array}{l}\text { Fire the first } 2 \text { rows of the millhole with any tight slot that crosses a millhole } \\
\text { intersection. }\end{array}$ \\
\hline Slot starter rises & $\begin{array}{l}\text { Locate rises at a slot } / \text { millhole intersection, for ease of redrilling in case of any } \\
\text { problems. }\end{array}$ \\
\hline
\end{tabular}

The bridges had to be broken so that overlying backfill from the old ROB5 stope would flow into the slot after mucking. Bridging was due mainly to loss of blast gases into open sub-horizontal stress-induced fractures located below the old 24 Level undercut drive, and also due to long up-holes, a narrow slot and initially inappropriate patterns and powder factors.

Pillar. The thin pillar of rock in the slot near millhole D experienced only small magnitude seismicity except for the $M_{R} 1.7$ event on 4 June 2007. It yielded on the west-dipping S1 structure during that seismic event. Interestingly, this compares well with a previous pillar between the I2 and S1 stopes, which yielded in 1998 via about a dozen events of $\mathrm{M}_{\mathrm{R}}+1.5$ to +2 . That was a larger pillar, intersected by the west-dipping Shea and Flanagan Faults as well as several subvertical structures.

The slot pillar was stoutly shaped (Width/Height=1.8) and stable prior to the seismic event. Afterwards, being damaged, it probably assisted rather than hindered the TSB concept, by allowing gradual closure of the slot, gradual shearing and gradual release of stored strain energy (largest $M_{R} 0.0$ subsequent to the 4 June 2007 event). 
Blast Ring Design. In hindsight, the first few firings of the slot were too "soft" and unable to pull the slot. When the powder factor was increased, pulling was better, but brow damage also increased. Moving from a 3 to a 5-hole ring was also a significant improvement.

Expansion Void. The target TSB blast expansion space was low, at 15\% to $25 \%$, including adjacent slot and drive void. Electronic detonators were used. A previous destressing experiment at Mt Charlotte for the 1301 millhole 3 slot used an expansion space of $18-19 \%$.

Explosives and Timing Issues / Powder Factor. The TSB blast of 28 March 2007 only broke ground up to $11 \mathrm{~m}$ above $25 \mathrm{Level}$, due to emulsion product slipping down the blastholes before initiation. Issues were the large $110 \mathrm{~mm}$ diameter of the holes (allowing product to slump) and extended timing sequence (allowing time to slump). Methods of improving product retention were considered, such as hanging a retainer system from the top (toe) of the hole, but the only viable solution appeared to be to use ANFO in inclined (not vertical) holes of $102 \mathrm{~mm}$ diameter or less.

Different timings were tried. Strong versus gentle blasts were considered. The volume of rock broken at one time is generally more significant for seismicity than is the quantity of explosives. Firing a small volume usually caused less stress change (unless a structure sheared significantly), therefore using a higher powder factor to ensure the blast pulls was considered appropriate.

Fractures. Loss of blast gases into cracked and open ground below the floor of the old Trough Under-cut (TUC) drive on 24 Level has also been blamed for several bridges. A horizontal open fracture was observed about $1 \mathrm{~m}$ below the floor of the 24 level TUC, which happened to be intersected in the separate 2490 workings. Cracks are likely to be horizontal and a function of high stresses beneath the TUC. Local movement and dilation of structures is also highly likely.

Initial slot blasting experience had suggested the presence of flat structures about $2.5 \mathrm{~m}$ apart below the TUC. For perhaps similar reasons, other mines typically have extreme difficultly firing highly stressed crown pillars, say to expose cemented fill. It would seem that sub-horizontal cracks beneath old stopes and in crown pillars are more common than generally thought, and they can significantly compromise blasting.

The flat quartz veins also proved to be significant to blast performance. Quartz is relatively weak, and in the high horizontal stress field, shallow dipping quartz veins are more likely to be already fractured and open up during blasts.

The poor quality rock mass in the hangingwall of Shea Fault was also significant. Blast holes passing through this poor ground have a greater chance of becoming blocked. Subsequent blasts have more chance of causing separation at the fault.

The mine has learnt the lesson that directional blastholes had to be used, specifically oriented depending on the controlling structures in the blast.

Brows/Redrilling. Drilling issues and recovery of blasthole collars after firings was an ongoing problem. In the highly structured and broken ground, wedges and blocks loosened by blasts could shift or fall, denying access to the next ring of blast holes, or causing other drilling issues.

Drillers reported that the worst ground was usually just south of the brow of the slot, cracked and fractured, with perhaps $2 \mathrm{~m}$ of broken ground before getting through to solid rock, extending for about $4 \mathrm{~m}$ ahead of the brow.

Single strand $3 \mathrm{~m}$ cables were installed in all brows that were formed by TSB blasts. To manage this issue in future, shotcreting over the existing mesh and bolts could be considered, particularly above intersections.

Slot rises. In hindsight, slot rises positioned at intersections of the slot and millholes would have permitted access from two directions for any redrilling requirements. This was the case for the I-millhole rise and it considerably simplified blasting issues at that location. 


\section{Ground support}

As part of this project, an empirical design chart for dynamic support was developed (Mikula and Lee, 2007) to ensure ground support would be adequate for the expected seismicity.

The combination of bulbed cables grouted into over-drilled split-sets was an effective reinforcement element for the prevailing blocky and seismic conditions on 25 level. The cable bolt was $3 \mathrm{~m}$ long with a single bulb positioned $0.2 \mathrm{~m}$ from the end, and was not plated or tensioned. This combination support element has also been able to reduce bagging (Figure 4). The installation practice was to drill a $3 \mathrm{~m}$ deep borehole, install a $2.4 \mathrm{~m}$ long split-set, insert the grout hose to the $3 \mathrm{~m}$ depth and fully grout the hole while withdrawing the hose, and then push a bulbed cable into the split-set until only $0.1 \mathrm{~m}$ was left protruding.

Grouting improved the stiffness (capacity / length) of the split-set, and the cable was well anchored by the grouted bulb above the split-set. No failures of this support element have been observed, but a few were seen to take load (cable ends unwinding). This indicated that the system was providing increased static capacity, compared to split-sets alone, plus it was soft enough to survive some dynamic loading.

This support system has merit and laboratory investigations are suggested to investigate and better understand the loading mechanism, and test the dynamic capability of the bolt. However, major seismicity has not (to date) occurred in the close vicinity of these elements, other than in G millhole, so their performance under dynamic conditions is not exhaustively tested.

It was noted that the conebolts (installed in about 1996) survived the 18 January 2007 seismicity, whereas some of the nearby split-sets (in a small area in B millhole, Figure 4) did not.

The 2514 footwall drive backs had been severely damaged during the 1997 seismic event (Figure 5). Planning in 2005 had anticipated the possibility of new seismicity on Shea fault affecting the drive. Therefore the drive was rehabilitated by thorough scaling back to sound rock, re-meshing with $3 \mathrm{~m}$ split-sets, then shotcreting through the mesh to $75 \mathrm{~mm}$ minimum, wrapping into the walls. The grouted split-set / bulbed cable combination bolts were also installed throughout this area. The broken nature of the ground precluded installing resin bolts. To date, this support has functioned very well. No further seismic activity has directly impacted the area, and it appears that this area had been destressed by the earlier seismicity.
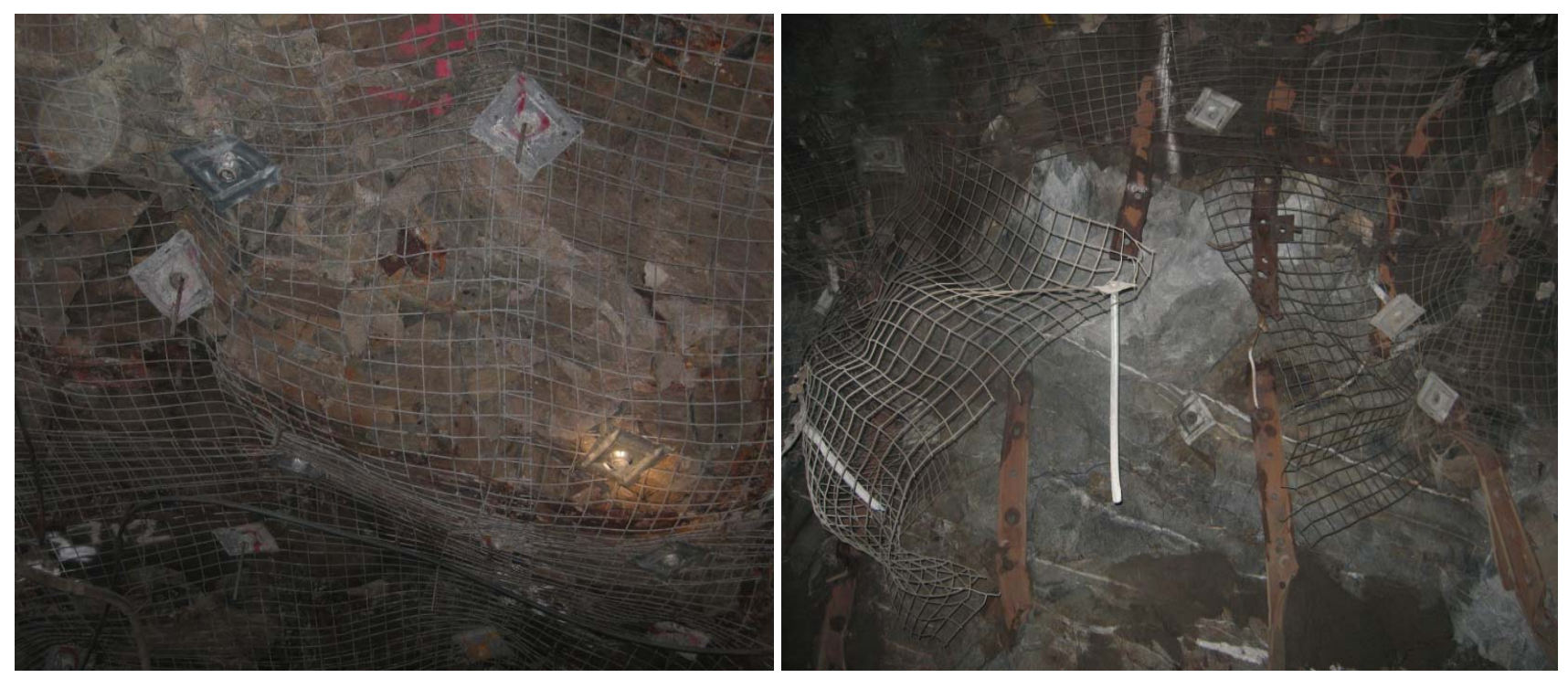

Figure 4 Ground support performance: (left) Bagging has been reduced by the combination unit of a bulbed cable grouted into an over-drilled split-set; (right) significant seismic damage in millhole B: conebolts survived while split-sets failed 

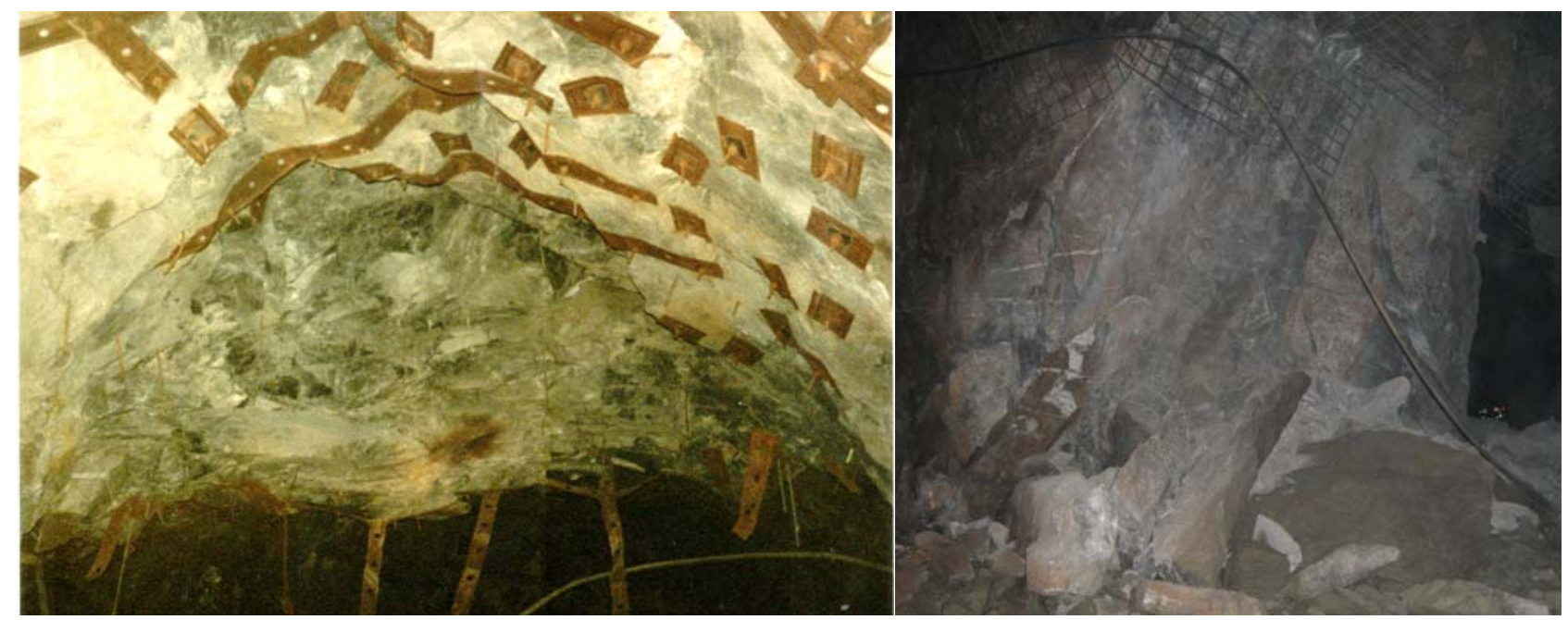

Figure 5 Seismicity damage: (left) The fracturing developed above the 2514 backs due to seismicity on 17 March 1997; (right) Wall failure due to shearing on Shea Fault on 18 Jan. 2007

\section{Seismicity response}

As noted earlier, large seismic events in 1995 and 1997 had sheared several structures (R3, R3A, R4, R5 and Shea). Figure 5 shows the sub-horizontal fracturing that occurred with the 1997 events above the backs of 2514. This fracturing, along with other extensive damage along 2514, indicates that some east-west closure had occurred, which would have reduced the local east-west stresses (i.e. destressing had occurred in the rock volume that was selected as the final slotting closure pillar).

At the start of this project there was debate as to whether those events had adequately destressed that portion of the 25 Level. Experience and observations have now shown that destressing did occur. The previously mapped damaged area from these events corresponds well with ground that now shows only low-level seismicity.

Table 4 is a comparison of the 2004 seismic forecasts (Sharrock, 2004) with what actually happened during the extraction of the R52 stoping block. The data in Table 4 shows that except for the Shea, the TSB strategy has provided the required control of event magnitude.

Table 4 Comparison of actual seismicity and the 2004 Forecasts

\begin{tabular}{|c|c|c|c|c|}
\hline Structure & $\begin{array}{c}M_{R} \text { Forecast best case, } \\
\text { i.e. with TSB } \\
\text { strategy }\end{array}$ & $\begin{array}{c}M_{R} \text { Forecast worst case, } \\
\text { i.e. without a TSB } \\
\text { strategy }\end{array}$ & $\begin{array}{c}M_{R} \text { Actual } \\
\text { largest event }\end{array}$ & $\begin{array}{c}\text { Date of largest } \\
\text { event }\end{array}$ \\
\hline $\mathrm{R} 2$ & 1.9 & 2.9 & 1.8 & 21-Apr-07 \\
\hline R3A & 1.9 & 2.5 & 0.7 & 20-Apr-07 \\
\hline R3 & 1.5 & 2.3 & -0.1 & 19-Jun-07 \\
\hline $\mathrm{R} 4$ & 1.9 & 2.3 & -0.2 & 23-Dec-06 \\
\hline R5 & 1.3 & 2.0 & 0.5 & 08-Мay-07 \\
\hline Reward & 2.2 & 2.7 & 1.0 & 09-Jul-07 \\
\hline Shea & 2.0 & 2.6 & 2.2 & 18-Jan-07 \\
\hline S1 & Not forecast & Not forecast & 1.7 & 04-Jun-07 \\
\hline Flanagan & Not forecast & Not forecast & 0.9 & 27-Mar-07 \\
\hline
\end{tabular}


The largest event recorded to date during the project was $\mathrm{M}_{\mathrm{R}}+2.2$, compared to target maximum of +2.3 . It was on Shea fault, which while not effectively destressed by the slotting, was restrained by backfill in the slot. An example of the seismic damage is shown in Figure 5, while the overall seismic response is summarised in Figures 6 and 7.

Seven of the thirteen largest events occurred within 78 minutes of blasting, and exposure was effectively managed by the re-entry window. However the other six (including the two largest) effectively occurred randomly. The TSB procedure therefore inadequately controlled event timing.

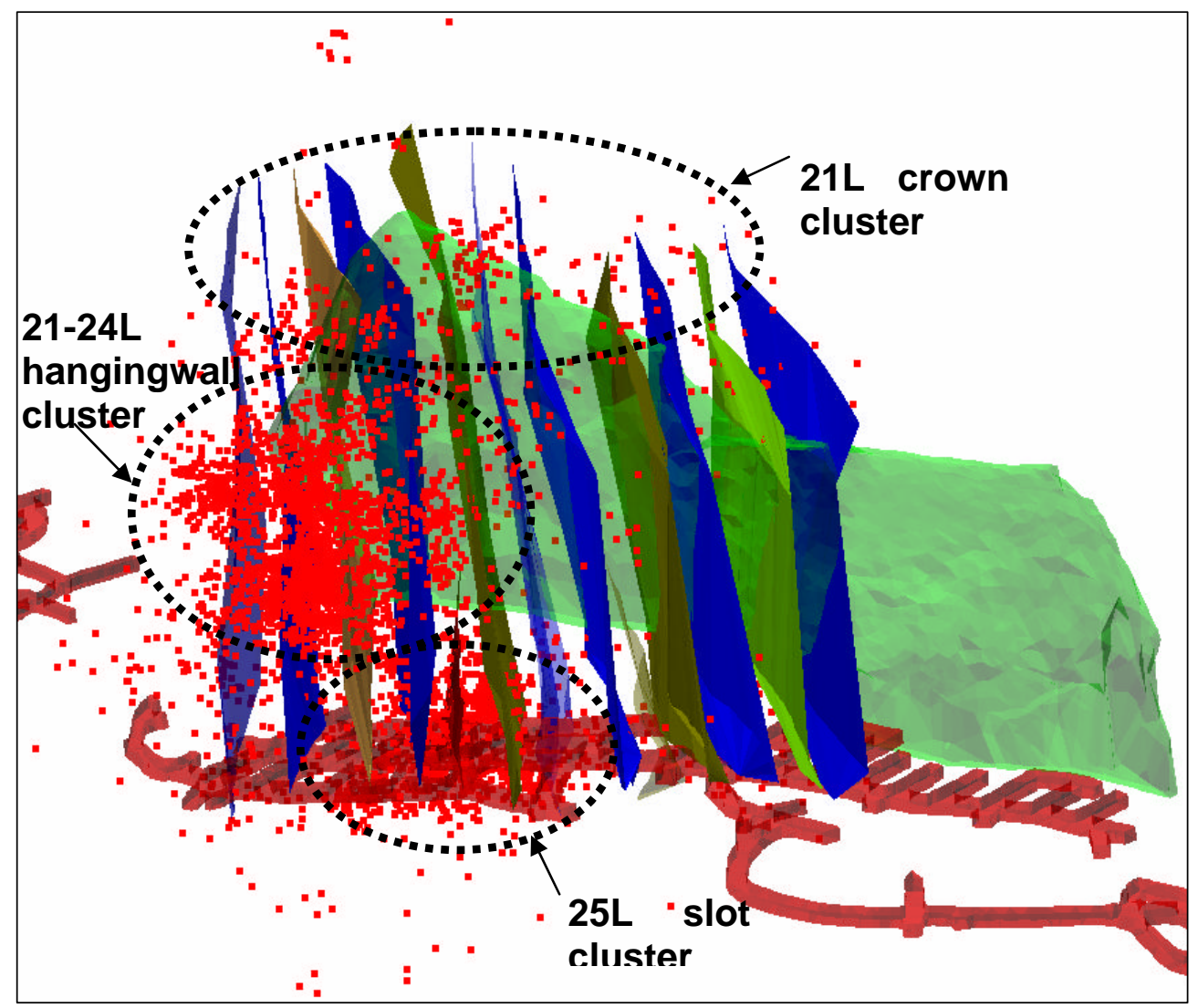

Figure 6 Perspective view showing the location of seismic events

Seismicity was a good indicator of the progress and extent of destressing (Figure 6). Until May 2007, events occurred dominantly within $20 \mathrm{~m}$ of the northern slot brow. The turning point was the 4 June 2007 shear event on S1 (Figure 7). From then, there was a reduction in seismicity near the brow, and a very marked increase in seismicity up to $100 \mathrm{~m}$ distant from the slotting.

The southern slotting and the interval from G to L millhole have had consistently far fewer events than the northern half of the stoping block. Events extended up to $70 \mathrm{~m}$ west of the northern slotting area.

It is of interest that for the major seismic events, damage was primarily restricted to below Shea fault and below the S1. Review of seismic event locations shows that a majority of events are clustered below either the Flanagan or the Shea Fault. This is a geometry effect - the fault footwalls have somewhere to move to, while the hangingwalls do not.

It seems that moderate west-dipping structures, within about $20 \mathrm{~m}$ of the base of the R52 slot (and also similarly in respect to the 24A previously, and the original 24 Level undercut) were destressed by shearing as the slot passed. Further west of the slot, it appears that the stress field beneath the bottom of ROB5 becomes less adverse, and these structures do not have the same potential to shear.

Higher up the stope (21 to 24 Level interval), stope closure and loosening of the rock mass surrounding ROB5 again encourages shear on west-dipping structures (such as Flanagan). 


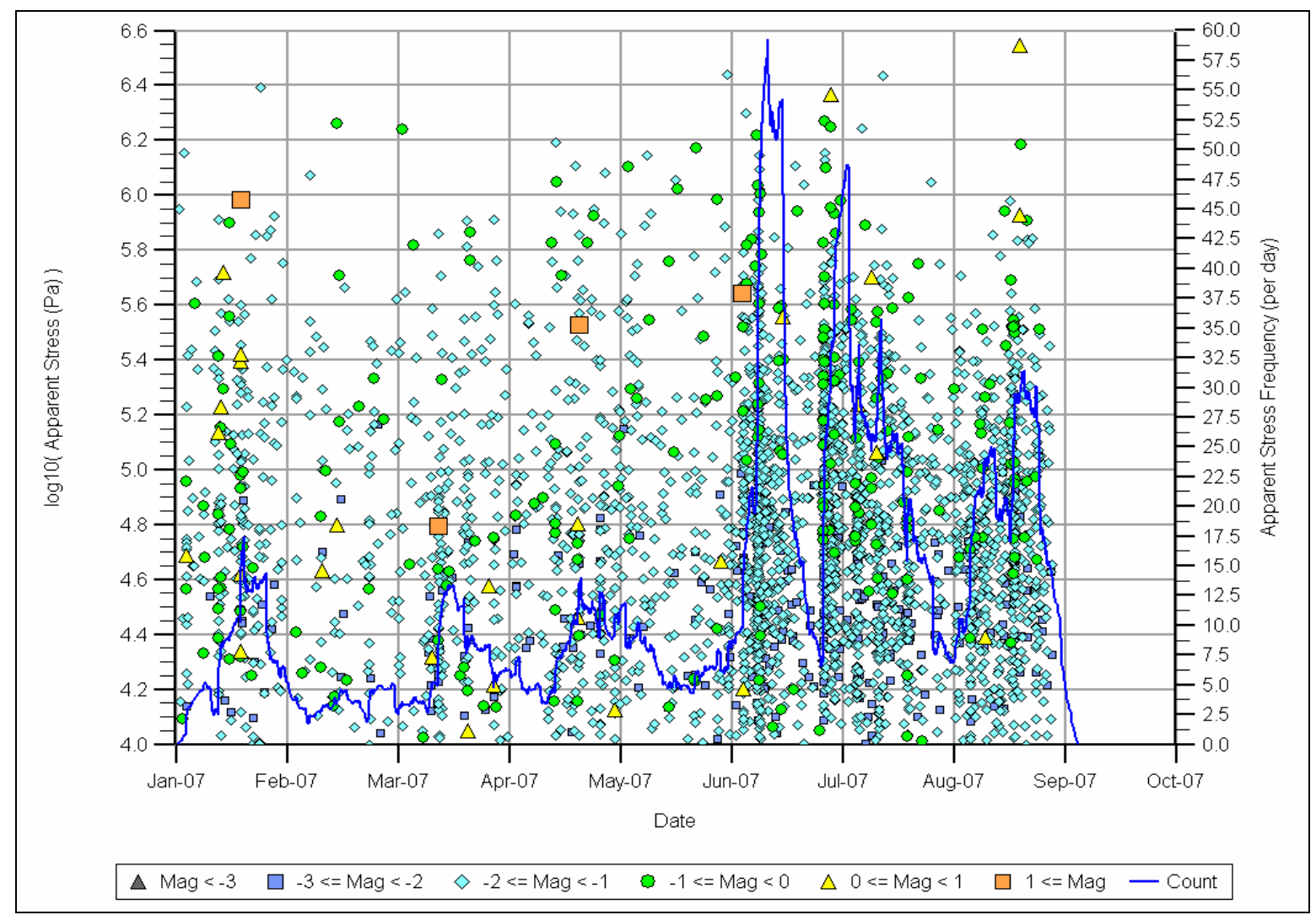

Figure 7 All ROB5 seismicity as a graph of Apparent Stress over Time, showing the change on 4 June 2007, and the correlation of higher magnitude events with peaks in the Apparent Stress Frequency. Apparent Stress is a measure of the relative amount of energy in a particular seismic event. The solid curve is the 7 day trailing average daily number of events with an Apparent Stress greater than a 10,000 Pa threshold

\section{$8 \quad$ Flatjack stress monitors}

Stress monitoring was critically important. Visual inspection of boreholes for stress-induced breakout was routinely done during the project, as an indicator of stress. Observations include the following:

- Old holes (drilled in 1997) for an abandoned boxhole rise at the north end of 2515 implied a maximum stress direction similar to that previously measured on 24 Level further to the south.

- Large-diameter holes drilled for the slot rises in 2515 showed no breakout, i.e. maximum stress less than perhaps $70 \mathrm{MPa}$, even near the end of the slotting process when the closure pillar was rapidly diminishing.

Six hydraulic flatjack monitors were installed late January 2007 to track stress changes along the slot. They have been useful diagnostic tools (Figure 8). The monitors needed to have sufficient range to adequately track the large stress changes anticipated close to slots. They were installed approximately $5 \mathrm{~m}$ into millhole backs, in short Jumbo stub holes drilled into the ends of previously drilled $76 \mathrm{~mm}$ diameter Simba holes. They were oriented to read the horizontal east-west stress component, and pumped to $30 \mathrm{MPa}$ to set them in the holes.

As of 29 August 2007, two units were still functioning despite significant seismicity and blasting damage to the surrounding rock. Typically the flatjacks remained functional until the stope brow was only two rings away. CSIRO HI cells were previously considered as an alternative to the flatjacks. While the data would have been three dimensional (technically superior), monitoring data would have been more difficult to collect and slower to process. It is also unlikely that they would have been as rugged as the flatjacks and still be operating. 
The stress changes monitored show that the ground responds to mining, also that pillars and asperities influence the stresses, and stresses can change quickly. The flatjack readings took some time to stabilise after installation. In summary, after stabilisation, destressing of up to $19 \mathrm{MPa}$ was recorded.

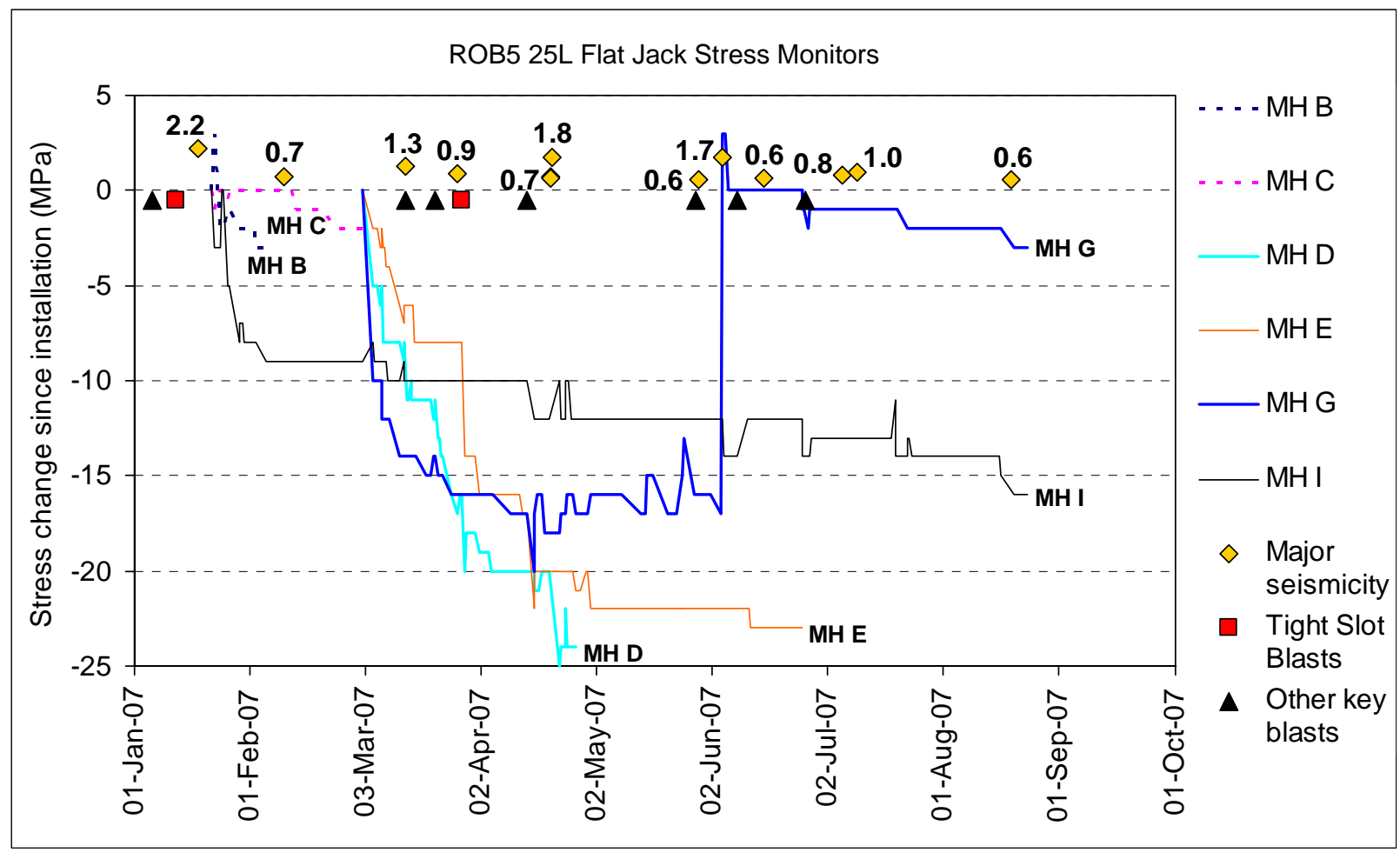

Figure 8 Stress changes recorded by the flatjack monitors (monitor locations are shown in Figure 3)

\section{Improvements for future TSB destressing projects}

Much knowledge has been gained through experience of Tight Slot Blasting and has been documented throughout this paper. Several over-riding principles have become very apparent:

- Good access. Development drives both top and bottom of the slot are essential to assist slotting:

o These would have improved the understanding and interpretation of the structures and open cracks which significantly compromised blasting from the 2515 access. It may have been possible to use geophysical surveys between the drives to better define structures and assess stresses in the bottom ROB5 abutment or slot.

o Down holes could have been used for blasting the slot and dealing with any bridging, and mining through structures would have been easier. The requirement to work under stressed or damaged brows would have been reduced. The outcome would have been better control of seismicity.

- Destress every structure. Previously, the sub-vertical R-shears were considered to be the critical structures. This was true, but in hindsight Shea Fault and S1 (moderately west dipping) also proved to be prone to shearing and associated seismicity. It is difficult to image how both the steep R-Shears and the moderate west dippers could have been destressed by a single slot. Hence specific destressing of each structure needs to be considered.

- Maintain tight fill in place. The original TSB concept required that the fired rock was not mucked or loosened, but that it should remain in place until the SLC millhole extraction retreated away from it. However this did not happen due to bridges formed across the slot and production requirements for tonnes. These circumstances increased the seismic hazard - both the chance of seismicity and the magnitude of possible events. 
- Small pillars may not easily yield. While the original TSB concept avoided pillars, a variation on the TSB technique could be to include small pillars designed to yield gradually. These would be left at or close to intersections of the slot with millholes, for ease of access for blasting if so needed. This is a similar concept to the pillar preconditioning that was used in 1995 to manage high stresses in the I1 rib pillar (Mikula et al., 1995). Yielding pillars must be smaller than the slot pillar that developed during the ROB5 project, and must have a yielding mechanism. However, while a small pillar remains, it can still buttress structures against shearing. There is therefore always a risk of seismic failure of such a pillar, with associated shearing of the buttressed structure.

\section{Acknowledgements}

The authors wish to express their appreciation to KCGM for allowing the destressing of ROB5 to proceed, and for permission to publish this paper. This project started with a simple sketch on the back of an envelope in the Rock Mechanics office at the mine back in 2002, and is finally reaching fruition. Our thanks to all who believed that one day ROB5 would be conquered.

\section{References}

Lee, M. and Fotakis, D. (1992) Charlotte Deeps: 29 Level Virgin Stress Measurement. James Askew and Associates, JAA 1724.

Mikula, P.A. (2001) Seismicity CS3 - 1380 area (Event No. 111729) on 18th November 2001. Internal Memo, KCGM Mt Charlotte, November.

Mikula, P.A. and Lee, M.F. (2002) Forecasting and controlling pillar instability at Mt Charlotte Mine. $1^{\text {st }}$ International Seminar on Deep and High Stress Mining. Australian Centre for Geomechanics, November.

Mikula, P.A. and Lee, M.F. (2007) Empirical performance chart for ground support in seismic conditions at Mt Charlotte. $4^{\text {th }}$ International Seminar on Deep and High Stress Mining, Australian Centre for Geomechanics, Perth, November.

Mikula, P.A, Lee, M.F. and Guilfoyle, K. (1995) Preconditioning a large pillar at Mt Charlotte Mine. Underground Operators Conference, Kalgoorlie, pp. 265-272.

Mikula, P.A., Sharrock, G., Lee, M.F. and Kinnersly, E. (2005) Seismicity Management Using Tight Slot Blasting for Stress Control at Mt Charlotte Mine. $6^{\text {th }}$ International Symposium on Rockburst and Seismicity in Mines, Perth, March.

Sharrock, G. (2004) Seismic Analysis of ROB5 Destressing. AMC Consultants Report No 204048 for KCGM Mt Charlotte, June. 